By MORRIS A. GELFAND

\title{
The College Librarian in the Academic Community
}

\section{Mr. Gelfand is librarian, Queens College.}

$\mathrm{T}$ $\mathrm{HE}$ position of the college librarian in the academic community can be clearly defined if there is real understanding and genuine acceptance by college administrators, classroom teachers and librarians, of the aims and purposes of the college. An understanding of the educational role of the library, as an instructional department whose main purpose is to further these aims and purposes, is also important.

As an educational agency of the college, the library complements and supplements the work of the teacher in the classroom by serving as a center for some of the most important materials of instruction. In the selection and organization of these materials the library staff works closely with its colleagues in the classrooms and acquaints itself thoroughly with the curriculum. Further, through its professional personnel, the library offers personal services in the form of guidance, counsel, and instruction, which, when fully utilized, occupy an important place in the education of the student and perhaps in the educational development of faculty colleagues as well.

If it is agreed that the primary purpose of the college library is to further the educational program of the college and that the duties of the librarian and the professional members of his staff are basically

1 Paper presented at the Conference of Eastern College Librarians, Columbia University, Nov. 27, 1948. instructional in nature (or should be), it should follow that the librarian and those of his staff who are qualified to perform their individual roles as professional librarians should have the status of members of the instructional ${ }^{2}$ staff of the college.

The instructional character of librarians' duties and their educational preparation has been recognized in the status accorded librarians in a number of well known colleges and universities. At the University of Illinois, in 1944, the professional staff was removed from civil service and granted academic status. ${ }^{3}$ Academic titles such as instructor or assistant professor are given to all professional positions (although such titles are actually employed only by staff members who teach) and salary scales now correspond with those of the teaching staff. At Stephens College, Columbia, Mo., all professional members of the library staff are regarded as faculty and the chief librarian is also Dean of Instruction. ${ }^{4}$ This is an unusual case but one that indicates acceptance of librarians as teachers and integration in a high degree between the

\footnotetext{
2It has been suggested that "academic" would be a more suitable term than "instructional" in this connection. My use of "instructional" arises from my experience in the municipal colleges of the City of New York. These colleges are governed by the by-laws of York. These colleges are governed by the by-laws of
the New York City Board of Higher Education in the New York City Board of Higher Education in
which all ranks of professional librarians are defined as members of "the instructional staff of the colleges." (See: New York (City) Board of Higher Education. By-laws of the Board of Higher Education of the City of New York. August 1939. p.r2, Section rora.)

Downs, Robert B. "Academic Status for University Librarians-a New Approach." College and Re search Libraries 7:6-9, January 1946.

4 Johnson, B. Lamar and Lindstrom, Eloise, eds. The Librarian and the Teacher in General Education: a Report of Library-Instructional Activities at Stephens College. Chicago, A.L.A., 1948.
} 
library and the classroom. Professional librarians of all ranks on the staffs of the municipal colleges of the City of New York are members of the instructional staff and have voting privileges in the faculty council. ${ }^{5}$ These are but a few of the many examples that can be cited to demonstrate recognition of library staffs as instructional personnel.

Unfortunately this recognition is too often limited to the chief librarian and one or two of his principal assistants. In some cases where the entire professional staff is classified as instructional it generally does not receive salaries and privileges comparable to those of classroom teachers. These subject of their faculty colleagues and the college administration;

2. The degree of participation by librarians in the work of college committees and other college organizations and their opinions concerning the value of such participation;

3. The status of the professional library staff with regard to the standing of the librarian as a responsible administrative and educational officer and the rank and salary given to the librarian and his professional staff;

4. The librarian and the faculty.

This is my report. It is offered only as an informal indication of present day conditions in some eastern college libraries. The replies are regarded only as suggestive

Table I

Status of the Library in the College

\begin{tabular}{|c|c|c|c|c|}
\hline Opinions of & $\begin{array}{c}\text { Library Is an } \\
\text { Instructional } \\
\text { Dept. }\end{array}$ & $\begin{array}{c}\text { Library Is an } \\
\text { Administrative } \\
\text { Dept. }\end{array}$ & $\begin{array}{l}\text { Library Is } \\
\text { Combination } \\
\text { of Inst. and } \\
\text { Admin. Dept. }\end{array}$ & $\begin{array}{l}\text { Nò } \\
\text { Opinion }\end{array}$ \\
\hline Librarians & 25 & 6 & 17 & 2 \\
\hline $\begin{array}{l}\text { Faculty Members } \\
\text { (according to Librarians) } \\
\text { College Administration }\end{array}$ & 19 & I5 & 10 & 6 \\
\hline (according to Librarians) & 15 & 16 & I3 & 6 \\
\hline
\end{tabular}

observations and others stem from data collected in a brief survey initiated by the writer in October 1948. The survey was designed to elicit information concerning the present day status of librarians in eastern college libraries. A questionnaire was sent to 70 chief librarians in liberal arts colleges, teachers colleges, and a few small universities. The first 50 replies were tabulated and studied. Questions were asked on the following points:

I. Whether librarians regarded the library as an instructional or administrative agency and their opinion of the attitudes on this

5 Bousfield, Humphrey G. "College Libraries with Dual Roles." College and Research Libraries 9:25-32, January 1948 . The latest of several articles written about the libraries of the municipal colleges of the City of New York during the last few years. of the conditions one might expect to find more generally. The sampling is too small and the method used is unsuitable for a statistically reliable conclusion.

\section{The Status of the Library in the College}

Fifty per cent of the librarians polled regard the library as an instructional department (Table I); 34 per cent look upon it as a combination of the instructional and administrative, while 12 per cent believe the library is an administrative agency. A most revealing statement comes from Florence L. King, librarian of Wellesley College. She writes:

"Is it as easy as 'either, or?' Isn't the library a department functioning as an administrative unit through an organization of 
resources and personnel serving educational goals? ... As a department, isn't the library organized for services in the interests of educational goals? Consequently, instruction formal and informal, direct and indirect, is included in the service program. The degree to which the department's services are instructional in nature depends upon the degree of library-curricular integration, does it not? The achievement of goals is related to the concepts of the library administrator(s), and the application of administrative policy, and the consequent functioning of the department as an administrative unit."

In agreement with Miss King are other librarians who find it difficult to draw a line between the administrative and instructional functions of the library. It seems clear enough, however, that relatively few librarians regard the library as an administrative agency in the same sense as, let us say, the president's office, the bursar's office, or the registrar's office. Librarians generally regard the management of a library as administrative but the function of the work performed as instructional.

Faculty members and college administrators, according to the librarians reported here, are more divided in their opinions concerning the status of the library. Of the faculties, 38 per cent regard the library as an instructional department; 20 per cent as a combination of the instructional and the administrative; 30 per cent look upon the library as administrative. Among the administrators, 30 per cent look upon the library as an instructional department; 26 per cent believe it is a combination of the instructional and administrative; and 32 per cent regard it as an administrative department. One librarian reports: "We consider ourselves instructional with a certain hybrid taint of administrative. The faculty and the administration do not tend to think of us as a department at all-but more as subject to the dictates of 200 in- dividuals of faculty status." If these reports are generally indicative of attitudes throughout the country it would not be difficult to explain why so many administrators still seem to regard librarians as high grade clerks.

\section{Committees and Organizations Served}

Relatively few librarians serve on any of the important college committees, other than the library committee. Ninety per cent serve on the library committee: 32 per cent as chairman, a few as secretary. Almost one-third serve on the executive council of deans and administrative officers; about one-fourth serve on the faculty council or senate. A surprisingly small number, seven, or 14 per cent, are on the curriculum committee. Thirty per cent serve on the library building committee where one is in existence.

On other committees where librarians might be presumed to be competent to make a contribution there is very small representation. These include the publications committee, the personnel and budget committee, the graduate committee, the research committee. Twenty-two per cent serve on committees dealing with public functions and ceremonial occasions.

Very few library staff members serve on committees according to this survey. When asked to account for this condition, librarians report in several instances that the nonfaculty status is the principal cause. Others indicate that staff members are "too busy" or "too young and inexperienced." One librarian comments: "Largely a matter of local habit. Faculty male, library staff two-thirds female."

\section{Degree of Participation in Committee Work}

Participation in committee work ranges from "almost negligible" to 20-25 per cent 
of the librarian's time. One-half of the librarians who report say that they spend from less than one per cent to five per cent of their time on committees and in other faculty activities. Among the remainder, six report spending to per cent; five, more than I4 per cent while the others say that they spend six per cent, seven per cent, and 12 per cent respectively. It would appear that among the librarians who report relatively few are overburdened with committee work.

\section{Relative Importance of Committees}

According to this survey, librarians believe membership on the following committees to be most important, taking into consideration the contribution they are competent to make and the benefits to be gained for the library. Listed in the order of their importance according to the frequency with which they are mentioned they are:

Per Cent

Library Committee ..............80

Library Building Committee ........52

Curriculum Committee ............40

Library Fund Raising Committee ....34

Executive Council ...............32

Faculty Council $\ldots \ldots \ldots \ldots \ldots \ldots \ldots 28$

Research Committee .............22

Graduate Committee .............22

These findings agree in part with those of Barcus $^{6}$ who, reporting the opinions of 52 librarians concerning the incidental duties of the college librarian, says: "The concensus would seem to be that the librarian of a college or university, apart from his 'regular duties,' will profit through membership on those committees whose proceedings affect the library most closelychiefly, the library committee itself, the executive council, the curriculum committee, and the committee on publications." In

6 Barcus, Thomas R. "Incidental Duties of the College Librarian." College and Research Libraries 7:1423, January 1946 . the present survey librarians regard the publications committee as of secondary importance. There is some doubt as to how librarians reporting interpret the executive council and the faculty council. If these two organizations are regarded as similar in function the combined vote for them would indicate agreement with Barcus' findings.

As to the value of committee work generally and the contribution the librarian might be competent to make, one librarian states: "The main contribution of the librarian may be his ability to see the whole academic picture, whereas so many professors cannot look beyond the vested interests of their departments." 7

\section{The Librarian as a Responsible Officer}

In 68 per cent of the libraries reporting, the librarians have equal status with academic department heads (Table 2). Many of these librarians, however, are also considered on the same plane with administrative officers of the college. Ten per cent of the librarians report equal status with deans. These, as might be expected, are generally in the larger colleges and in universities.

Table II

Status of the Librarian in the College

\begin{tabular}{lrrc}
\hline \hline $\begin{array}{l}\text { The Librarian Has } \\
\text { Equal Status with }\end{array}$ & Yes & No & $\begin{array}{c}\text { No } \\
\text { Opinion }\end{array}$ \\
\hline $\begin{array}{l}\text { Deans } \\
\text { Academic Dept. Heads }\end{array}$ & 54 & 18 & 27 \\
$\begin{array}{l}\text { Administrative Officers } \\
\text { (Bursar, Registrar, etc.) }\end{array}$ & 20 & 7 & 9 \\
\hline
\end{tabular}

\section{Rank and Salary}

This is an area of great confusion: 72 per cent of the chief librarians hold academic rank and of this number 56 per cent receive the same salary or more than teach-

? Felix E. Hirsch, librarian, Bard College. 
ing faculty of the same rank. Among those who hold academic rank 19 are professors; Io are associate professors; six are assistant professors; and one is an instructor.

In 24 per cent of the libraries reporting, faculty rank is accorded all professional members of the library staff.

The following conditions are found among reporting libraries:

I. In most cases where faculty rank is accorded, it is given to the librarian and one or two of his principal assistants.

2. Librarians have faculty rank (probably for payroll purposes) but do not have academic titles.

3. Librarians have faculty status but receive lower salaries than those paid to classroom teachers of comparable rank.

4. Librarians have academic titles but receive lower salaries than those paid to classroom teachers with the same titles.

5. Librarians receive the same salaries as classroom teachers but have no academic status.

In general, the reports indicate, library staff salaries are lower than those for the faculty.

Here are a few reports that indicate the wide diversity of practices in regard to rank and salary:

Vassar: "The librarian and members of the library staff in charge of major divisions of the library have academic rank proper to the scale on which their salaries are based. Staff may attend faculty meetings but only the librarian has suffrage."

Franklin and Marshall: "Librarian and assistant librarian have no specified rank but attend faculty meetings and have vote."

Wellesley: "Only the librarian and three research librarians have faculty status. These librarians are in the academic procession as assistant professors although rank does not appear in any official listing."

Smith: "Librarian and assistant librarians are faculty members. All members of the staff are entitled to join teachers insurance and annuity pension plan. All members are welcomed as members of the faculty club."

Pennsylvania State: "Library staff mem- bers are classed as 'academic' but do not have equivalent titles to match the teaching faculty."

New Jersey State Teachers College, Montclair: "Librarian, audio-visual department head and demonstration high school librarian are classified as instructor; professional assistants are classified as assistant instructor. Others are classified in the state civil service."

Municipal colleges, City of New York: "Librarians of the ranks assistant librarian to librarian are paid on the same salary scale as classroom teachers. Library assistants, the lowest ranking professionals and the most numerous, are paid on a separate schedulelower than instructors.

Lafayette: "Head librarian's salary that of full professor; other professionals receive salaries between those of instructor and full professor."

Wesleyan: "On a comparative rank basis library salaries are three or more lower. This differential is in our case partly due to the fact that our faculty and student body are entirely masculine, the library staff almost entirely feminine."

\section{The Librarian and the Faculty}

Most of the librarians reporting believe it is one of the primary responsibilities of the library to keep the faculty and some administrative officers informed about new books, developments in educational problems, bibliographies, changes in library policy and rules, and kindred subjects in which the faculty may be presumed to have an interest. They use various means to inform the faculty. These include: news sheets, bulletin board notices, informal reports at meetings; lists of new accessions, annual reports to the president. Brooklyn College Library is a good example of a library in which this responsibility is taken seriously. It publishes: a faculty library handbook, an audio-visual bulletin, a list of recent accessions and library news items, and through committees, informally and formally, it finds ways to keep the faculty well informed. 


\section{Summary and Conclusions from Survey}

This survey, however inconclusive from a statistical standpoint, suggests that the following conditions probably prevail today in many eastern college libraries:

I. Librarians are not in complete agreement as to the fundamental character of the library; that is, whether it is an administrative or an instructional agency, or a department in which are combined the functions of both. College administrators and teachers are even less in agreement on this subject.

2. Except for the library committee, relatively few chief librarians serve on the most important college committees.

3. Library staff members rarely serve on any college committees of importance.

4. Librarians spend relatively little time on committee work and other faculty activities.

5. Librarians consider only a few of the numerous faculty committees and organizations important, either from the viewpoint of the welfare of the library or in terms of the contribution they can make to them. Of these committees the curriculum committee is considered a most important one but relatively few librarians are appointed to it.

6. As a responsible administrative and educational officer the librarian ranks equally with academic department heads in the majority of the libraries polled. In many instances he also ranks equally with administrative officers like the bursar, registrar, and others, and in a few cases he is of equal rank with the dean.

7. In the area of rank and salary there is little uniformity of treatment as regards librarians and classroom teachers. Academic status is often given the librarian and an associate or assistant librarian or two, but the professional staffs as a whole generally do not receive academic status. Academic status when granted has not usually brought with it the same salary scales for librarians and classroom teachers. In some colleges librarians may vote in the faculty but they have neither rank nor faculty status. In too many colleges librarians' salaries are lower than teachers' salaries for comparable ranks.

8. Librarians generally recognize a primary responsibility to keep the faculty informed about new books, new developments in edu- cation, and in other subjects in which the faculty may be interested. This responsibility is fulfilled in many ways, formal and informal.

\section{How Can the Status of Librarians Be Im-} proved?

The position of college librarians can be improved by the establishment of a sound policy governing the status of the library and the library staff. ${ }^{8}$ Under the most desirable circumstances this policy would be formulated by the administration with the advice and consent of the library staff.

Such a policy should make provision for a clear statement of the educational aims and purposes of the college; the relation of the librarian to the administration; a definition of library resources and an assignment to the librarian of responsibility for these resources, wherever they may be located and however acquired. This policy should also provide a statement of the duties and responsibilities of the librarian. Further, there should be provision for a library committee and a clear statement that it should advise and inform, rather than administer and execute. Finally, there should be a clear definition of the relationship of the librarian and the library staff to the administrative and educational units of the college. In this definition I should hope to see the library staff unequivocally characterized as instructional in nature and entitled in so far as it is possible, to all the privileges of the instructional staff.

As instructional personnel all librarians from the chief librarian to the lowest ranking professional assistant should be accepted fully as members of the instructional or academic staff of the college. As far as it is practicable, they should receive salaries corresponding with those of the classroom

\section{(Continued on page 139)}

8 I have used as a basis for my suggestions on policy making the excellent statement contained in: Wilson, Louis R., Kuhlman, A. F., and Lyle, Guy R. Report of a survey of the University of Florida library for the University of Florida. Chicago, A.L.A., 1940. pp.
I 7-1 8 . 
Journal of Applied Physiology. 2ror Constitution Ave., Washington 25. v.r, no.r, July 1948. Monthly. $\$ 7.50$ $\$ 8.50$ foreign.

Journal of Legal Education. Duke Station, Durham, N.C. v. I, no. I, Autumn I948, Ouarterly. Free?

Journal of Range Management. American Society of Range Management, Mt. Royal and Guilford Aves., Baltimore 2. v.r, no.r, October 1948. Quarterly. $\$ 3.00$.

Korean Review. Thomas Kang, 445 Quincy St., N.W., Washington. v.r, no.r, June 1948. Semiannual. \$r.

Le Livre. I 6 Boulevard St. Germain, Paris 6. no.r, May I948. ro nos. a year. $\$ 4$.

Lusitánia. R. Actor José Ricardo, 3, r/c, Lisbon. v. I, no. I, May 1948. Monthly. $180 \$ 00$.

The Micro News. National Microfilm Association, Io Lafayette Ave., Hingham, Mass. v.r, no.r, March 1948. Bimonthly. Price not given.

The Microcard Bulletin. The Microcard Foundation, Middletown, Conn. no.I, June 1948. Quarterly? Free?

Die Musikforschung. Bärenreiter-Verlag, Kassel. v,r, no. $1,1948.4$ nos, a year. Mk. 24.

Naturwissenschaftliche Rundschau. Wissenschaftliche Verlagsgesellschaft m.b.H., Stuttgart. v.r, no.r, July 1948. Monthly. Mk. 7.20.

Neurotica. The Neurotica Publishing Co., 44381/2 Olive St., St. Louis 8. v.1, no.1, Spring 1948. Quarterly. \$2.

The New Central European Observer. 35 Pond St., London, S.W.r. v.r., no.r, May 15, 1948. Biweekly. $\$ 4$.

North Carolina Folklore. The University of North Carolina, Box ro50, Chapel Hill. v.r, no.r, June 1948. Frequency not given. $\$ 2$.

Oklahoma Law Review. University of Oklahoma Press, Norman. v.r, no.r, May 1948. Quarterly. \$5.

Pakistan Horizon. Pakistan Institute of International Affairs, Fere Hall, Karachi, v. 1, no. I, March 1948. Frequency not given. Rs, 8 .

Personnel Psychology. I 727 Harvard St., N.W., Washington 9. v. $\mathrm{x}$, no.r, Spring 1948. Quarterly \$6. Foreign $\$ 7$.

Physics Today. American Institute of Physics, 57 East 55 th St., New York 22. v.I, no.r, May 1948. Monthly'\$4.
Plant and Soil. Martinus Nijhoff, The Hague. v.r, no.1, January 1948. 4 nos. a year. Guilders 20. Poesi. Wahlström \& Widstrand, Regeringsgatan 83 Stockholm. no. I, I948. 4 nos. a year. Free to members of Lyriksamfundet.

Prisma. P. A. Norstedt \& Söners Förlag, Stockholm. v. $\mathrm{x}$, no. $\mathrm{I}, 1948.6$ nos. a year. kr. 14.

The Quarterly Journal of Experimental Psychology. W. Heffer \& Sons, Ltd., Cambridge, Eng. v.r, pt.r, April 1948. \& I ro s.

Revista de Economia. Eurico Colares Vieira, Apartado no. $4_{42}$, Lisbon. v.1, no.r, March 1948. Quarterly, $55 \$ 00$.

La Revue du Chef d'Entreprise. Editions Ocia, 3 Rue Cardinal Mercier, Paris, no.r, 1948. Monthly. 600 frs.

Der Städtetag. W. Kohlhammer Verlag, Stuttgart, v.r, no. $1 / 2$, July/August 1948. Monthly. Price not given. The Swan of Avon. The Melander Shakespeare Society, Santa Barbara, Calif. v.r, no.r, March 30 , 1948. Quarterly. Price not given.

Taiwania, Laboratory of Systematic Botany, Dept. of Botany, College of Science, National Taiwan University, Taipei, Taiwan, China. v.r, no.r, May 1948 . Irregular. $\$ 7$.

Wald und Wild. Lothar Sauer-Morhard Verlag, Würz berg. v. I, no. $1 / 2$, September 15, 1948. Monthly. Mk. 12 .

World Politics. Yale Institute of International Studies, 202 Hall of Graduate Studies, Yale University, New Haven. v.r, no.r, October 1948. Quarterly. $\$ 5$.

World Trade Review. American Register World Trade Review, 170 Broadway, New York 7. v.r, no. I, February 1948. Monthly. \$1,50.

Your Human Relations. Public Relations, Inc., 522 5th Ave., New York, 18. v.r, no.r, January 1948. Monthly $\$ 5$. Foreign' $\$ 15$.

Zeitschrift fiir Angewandte Physik. Springer-Verlag, Heidelberg. v.r, no.r, January 1948. Monthly. Mk. 7.50 ,

Zeitschrift für Elektrotechnik. Ferdinand Enke, Stuttgart. v.r, no.r, April 1948. Frequency not given. Price not given.

Zeitschrift fïr Religions. und Geistesgeschichte. E1wert-Gräfe und Unzer Verlag, Marburg. v.r, no.r, r948. Quarterly. Mk. 6 per issue.

\section{The College Librarian in the Academic Community}

\section{(Continued from page 134)}

teaching staff, and they should be accorded the same privileges as all teaching staff with respect to tenure, sabbaticals, salary increments, and retirement. They should receive generous vacation allowances and special arrangements should be made, when possible, to permit them to pursue graduate studies. Library staff members should be invited to participate in those faculty and general college committees on which they are qualified to make a contribution. As head of an important instructional department the chief librarian should enjoy equal status with other instructional department heads. In those instances where the library is large and its resources and services warrant, he should be given equal status with deans and other high administrative officers. These suggestions may shock some college administrators and even a few college librarians. They are submitted in friendly and constructive spirit as-logical conclusions to be drawn from acceptance of the position that college libraries are important educational agencies and their professional staffs are clearly instructional personnel. Given equal status with other instructional personnel the college library staffs can be expected to participate actively and effectively in the affairs of the college and to contribute in high degree toward the attainment of its aims and purposes. 